\title{
7. The Language of Property: Analyses of Yolngu relations to country
}

\author{
Ian Keen \\ The Australian National University
}

\section{Introduction}

Among his many significant contributions to Aboriginal studies, Nicolas Peterson, in the 1970s, brought a fresh perspective to bear on the question of Aboriginal relations to land. L. R. Hiatt (1962) had questioned the validity of Radcliffe-Brownian orthodoxy on 'local organisation', drawing a vigorous defence and elaboration from W. E. H. Stanner (1965). Stanner's synthesis provided a language for analysis, which has endured, especially his distinction between a clan's 'estate' and a residence group's or band's 'range'. Neither Hiatt nor Stanner (or indeed Radcliffe-Brown) had spent time living and moving with an Aboriginal band through the course of a year. Peterson's fieldwork was unique in the Australian context in that he lived for a full year with a Yolngu band on the south-eastern margins of the Arafura Swamp in north-east Arnhem Land, largely without external provisioning (Peterson 1971). Consequently, his findings about movement, the ownership of land and waters and the composition of residence groups have a particular authority.

Peterson succeeded in bringing together the twin poles of an analysis begun by Radcliffe-Brown - namely, the contrast between, on the one hand, the totemic connections of a patrilineal 'clan' to its totemic sites and 'estate' (Stanner 1965), and on the other, the composition and foraging 'range' of the residence group or 'band'. Radcliffe-Brownian orthodoxy held that the main members of a band were men of a clan, plus their wives and children, and minus their married sisters and daughters, who lived patri-virilocally on their husbands' clan lands. Several of Radcliffe-Brown's students found this model wanting in their own fieldwork, as Peterson (2006) has recently shown, but Radcliffe-Brownian dogma prevailed and they suppressed those findings. Stanner (1965) had freed up the model somewhat, but Peterson gave a revised model new empirical and theoretical foundations. 
Peterson's approach to Yolngu relations to land drew on ethological theory of the time, concerned as he was with the 'territorial behaviour' of a population and 'spacing mechanisms' (Peterson 1972: 28; see also Allen and Barber, this volume). He also invoked sentiments of attachment to land as a motivating force behind spacing behaviour, arguing that the emotional attachment of older men to ancestral places on their own patri-group country gave particular shape to the multiple connections of individuals. Drawing on the concept of the 'developmental cycle of domestic groups' (for example, Fortes 1958), Peterson modelled some of the possible pathways open to women in their choice of residence, and men's choices about their own and women's residence, with their resulting patterns of residence-group structure. Older men tended to retain their daughters within their own residence groups for their labour, leading to the uxori-patrilocal residence of daughters' husbands. An alternative strategy for men was to marry polygynously. Patri-groups tended to be anchored to the clan country of older men of the group because of their attachment to the clan's estate and its sacred sites, to which they were disposed to return. ${ }^{1}$ The analytical terms used by Peterson, then, are centred primarily on notions of 'attachment' and 'sentiment'. He also uses the language of rights; in discussing the evolution of a system of territoriality based on totemism, for example, he writes of the 'restrictions and rights' surrounding the ownership of clan designs and rituals, and rights associated with shared territory as against individual kinship ties (Peterson 1972: 29).

This chapter argues that the language of 'rights' has dominated anthropological discussions of property, including land tenure. It has also dominated discussions of Aboriginal relations to land (as well as wider Indigenous relations) in the land rights era following the enactment of the Aboriginal Land Rights (Northern Territory) Act (1976), and again following the Mabo case and the subsequent native title legislation (Bartlett 1993). The language of rights developed during the evolution of the market economy through the early modern and industrial eras in Britain and other European countries, and is specific to a particular social formation, albeit widely exported through colonial expansion. Furthermore, concepts of 'rights' and 'property' are contested in legal studies and anthropology. It is rather extraordinary, then, that anthropologists use concepts whose meanings have been taken to be so problematic as if they were transparent instruments for translating concepts in other cultures. It is

1 Other studies have brought out the complementary attachment of people to their mother's and mother's mother's country, among others, so that the resulting patterns, found in Shapiro's (1973) study of the structure of Yolngu residence groups in the same period as Peterson's research, and in more recent studies of Yolngu homeland centres or 'outstations' (Morphy 2008), are more complex in the wider regional context. (See Keen 2004 for a synthesis of Yolngu residence patterns). 
also strange that they appear to have worked so well, although their success could be illusory in the sense that their use has given rise to distortions and misunderstandings.

Following brief reviews of analyses of property in anthropology and legal scholarship, this chapter contrasts Peterson's ethological approach to Yolngu relations to country with Nancy Williams' (1986) analysis, which deliberately uses legal terminology, and Fiona Magowan's approach, which draws on concepts of 'consubstantiation' and 'polymorphism'. In asking how the terms in which such analyses are cast might be reconciled, the chapter returns to Peterson's approach; this avoids the constraints imposed by the language of property and rights, and adumbrates forces that underlie 'property' in land and waters.

\section{Anthropologists on Property}

The concepts of 'rights' and related 'duties' or 'obligations' are essentially contested; the meanings of these terms are by no means transparent, and they have been and continue to be debated in philosophy and legal scholarship. How have anthropologists analysed 'property' relations?

Robert Lowie (1947: 243) distinguished between individual and collective or communal property, and between 'real estate' and 'moveable property' or 'personal property' (pp. 216, 233). He thought that 'purely personal titles' were more clearly established in 'primitive society' than titles to land, and that 'title' to moveable property often 'rests on individual effort' (pp. 233-4). Communal or collective ownership was not uncommon (p. 206), however, but Lowie cites evidence for private ownership in 'primitive society' to counter the stereotype of primitive communism (p. $208 \mathrm{ff}$ ).

Together with 'use', the element of 'control' has been picked out by Goody (1962: 290) as underlying the concept of property, while other writers bring out use, possession, exclusion and disposal (see Keen 1991a: 272). Barnard and Woodburn (1991: 13) also emphasise control; a property right involves a particular type of association between a person and a thing — namely, 'a measure of socially recognised "control" over the "thing" and which necessitates some restrictions on other people's control of the same "thing"' (p. 13). They use the expression 'property rights'

for the variety of rights - especially rights of possession, of use and of disposal - that may be held in or over 'things' - for example, in land, in tools and weapons or in food. But the term is also appropriate for rights in less tangible things - the right to perform a piece of music, or to carry out a particular ritual. (Barnard and Woodburn 1991: 13) 
A close association between a person and a thing does not entail that the thing is the person's property in the usual sense 'unless some other people are in some way restricted in their use of it'. (This is the element that legal scholars sum up as exclusion.) Thus, property rights, whether individual or joint, are 'held in opposition to those who do not hold such rights' (Barnard and Woodburn 1991: 13). They go on to extend the expression 'property rights' to certain rights over people, their labour and reproductive capacity, such as a football club's rights over players, or rights to bestow female kin in marriage (p. 13). Barnard and Woodburn (1991: 14) propose a typology of property rights, cast simply in terms of kinds of things owned: land, water and its resources, moveable property, game meat, vegetable food, capacities of people, knowledge and intellectual property (cf. Altman, this volume, for another discussion of notions of property). As I noted at the beginning of the chapter, Peterson's discourse about Yolngu relations to land and waters mentions rights but is not dominated by this concept, concerned as it is with attachment. He addressed legalistic concepts more directly in his many writings about anthropology and the NT land rights legislation (for example, Peterson 1985).

In a recent collection, Von Benda-Beckmann et al. (2006) apply the 'bundle of rights' construct to cross-cultural analysis. Property concerns 'the organisation and legitimation of rights and obligations with respect to goods that are regarded as valuable' (Von Benda-Beckmann et al. 2006: 2). More specifically: 'Property in the most general sense concerns the ways in which the relations between society's members with respect to valuables are given form and significance' (p. 14). These authors suggest that the 'metaphor of the bundle of rights' should serve as a framework for cross-cultural analysis and should be taken seriously 'in order to capture the different roles that property may play, as well as the complexities and manifold variations of property in different societies and in different periods of history' (p. 3). They suggest that the metaphor has been used to conceptualise property as the totality of property rights and duties as conceptualised in any one society, and as any specific form, such as ownership (which can be thought of as a bundle of rights). It can also be used, they suggest, to characterise the specific rights bundled in a single property object, and to characterise the different kinds of property held by a single social unit (p. 15). Most of the contributors to their edited volume follow this general approach. The 'bundle of rights' concept has its origin in British legal history.

\section{‘Rights' in Legal Theory}

By the early twentieth century, property was no longer regarded in legal theory as 'absolute dominion', as in Blackstone's ideal, or as sui generis, but as a disaggregated 'bundle of rights'. The modern understanding of property 
as 'disaggregated' is traced to the writings of Hohfeld in the early twentieth century (Hohfeld 1913, 1917; see also Gordon 1995: 96), although scholars attribute the expression 'bundle of rights' to Maine (Hann 1998). The rights afforded by property were no longer absolutely distinguishable from those offered by other legal categories and no longer carried a clearly definable set of incidents (Davies and Naffine 2001: 36).

In summarising legal views of property, Davies and Naffine (2001: 6), like Goody, invoke the concept of control: 'A property right enables the proprietor to exercise control over a thing, the object of property, against the rest of the world.' In common-law countries, the terms 'rights' and the related 'duties' or 'obligations' are used to divide up ownership into 'incidents'; property becomes a 'bundle' of different kinds of 'rights'. Harris (1996) construes ownership in terms of bundles of rights with an 'ownership spectrum' ranging from ownership in its fullest sense to a use right as 'mere property' (Pottage 1998: 332). Other European legal systems, also influenced by Roman law, have parallel concepts.

In a common view, things as such are not owned as property but rather 'socially recognized rights of action' are owned (Alchian and Demsetz 1973: 17). Like some others, Alchian and Demsetz (1973) conceptualise the division of rights as arising from the control of resources. The domain of demarcated uses of a resource can be partitioned among several people and more than one party can claim some ownership interest in the same resource. Thus, '[i]t is not the resource itself which is owned, it is a bundle, or a portion, of rights to use a resource that is owned' (Alchian and Demsetz 1973: 17, emphasis in original).

\section{Property as an Essentially Contested Concept in Law}

In the very extensive literature on the meaning and ontology of rights, the imaginary or fictive nature of rights and duties has long been recognised and discussed (for example, Olivecrona 1971), demanding a theory of their true nature or of what they accomplish. Theories of rights have been concerned with the source and origins of rights, and have at the same time addressed their ontology. In one view, for example, rights and duties are abbreviated expressions for actual situations, such as the situation of constraint under which a party to a contract is placed (Olivecrona 1971: 139). Complicating the issue, there is a diverse range of views about the character of property in industrial countries. Discussions about the concepts of property and ownership have been occasioned by perceived changes in institutions, especially the apparent diversification and fragmentation of ownership brought about by governmental intervention 
(Van der Walt 1992). In light of such debates, Rey (1977) proposed a dynamic concept of ownership that develops according to changing circumstances - a 'process that works itself out in dialogue', in the words of Callies (1971: 121). According to a view that can be traced to Grotius (Van der Walt 1992: 447), a holistic, abstract concept of 'ownership' underlies the fragmented bundle of rights that comprises property. Harris (1996: 63n.1, 86) takes ownership not as a term of art in the law but as an 'organizing idea' and part of the taken-forgranted background for what we say (see Pottage 1998: 332). ${ }^{2}$

One aspect of the slippery nature of the property concept in Western law is the range of things owned, from tangible 'things' to rights owned by other parties (Worthington 2006-07: 924). All rights, Worthington (p. 939) observes, can perform the role of 'useable wealth'. If so, 'property' is indistinguishable from rights in general. Penner (1995-96: 802) proposes that a necessary criterion for treating something as property is that it is only contingently ours, and that property rights 'could just as well be someone else's'. This is not the case with bodily parts, although one can conceive of them becoming so. Our connection to our bodily parts is not contingent, although our rights are alienable in the sense that we can waive a right to assault in the case of a biopsy being taken (Penner 1995-96: 803). For an owner to have a right to a thing, 'there must be a distinguishable owner and a distinguishable thing' (Penner 1995-96: 803).

Perhaps property is an entirely illusory concept. Grey (1991: 252) offers a radical critique of the concept of property: 'the ultimate fact about property is that it does not really exist, it is mere illusion. It is a vacant concept-oddly enough rather like thin air.' This argument was occasioned in part by cases about the ownership of space above one's land, or between a part of a building and a plane projected vertically from a boundary, and by cases about visual access (such as to a racecourse) as property. Nevertheless, property has a functionnamely, to delimit the range of claims of meum and tuum. Such claims spring from 'the assertion of self-interest in the beneficial control of valued resources' (Grey 1991: 306-7). In such discussions, meum and tuum are taken as primitive or primary concepts underlying property.

Thus, Grey (1991: 306) reduces property to the control of resources and indeed to human nature: 'There can be little doubt that property thinking is deeply embedded in the human psyche' although the meaning of 'property' is 'strictly delimited'. Similarly, ownership 'orders the allocation of social resources as between individuals' (Harris 1996: 63, cited in Pottage 1998: 332). The core component is a notion of legitimised self-seekingness; as Pottage (1998: 332)

2 According to Penner (1997: 71-3, cited in Pottage 1998: 333), the powers and faculties of ownership depend on 'the juridical apprehension of a diffuse social understanding of ownership'. 
remarks: 'to be recognized as an owner in the fullest sense is to be accorded a sphere within which one might use or dispose of some resource just as one pleases.'

The point to be made here is that the language of 'rights' is far from straightforward; rights and duties are complex imaginary entities. In relation to property, the language of rights is a convenient device that enables 'owning' things to be broken up into specifications of the variety of things that owners may and may not legitimately do in relation to the thing owned and to other persons. A 'right' is an abstract or imaginary quality 'possessed' by an owner, which mediates the relation between the owner, other people, and the thing owned. The owner 'has' the right to act or refrain from acting in various respects vis-a-vis the thing owned. Non-owners 'have' duties in respect of their relation to the entity owned by some other person or body. I turn now to anthropological critiques of the use of concepts of property and rights for construing concepts and practices in other cultures.

\section{Anthropological Critiques}

Why should it be assumed that the concept of property can be applied to relations constituted in very different cultures? Hann contends that

[t]he most basic element in the anthropologist's approach to property (and to other key concepts) is to question whether the understanding that has emerged in Western intellectual traditions can provide an adequate base for understanding the whole of humanity. The English term 'property', in technical, legal and academic as well as in 'folk' understandings, is closely tied to the history of enclosures and the emergence of capitalism. How, then, can the patterns of access and use characteristic of precapitalist [sic] land tenure be described in terms of property relations? (Hann 2007: 289)

The English term 'property', he points out, cannot readily be translated into German, where Vermögen (ability, power, means, fortune, property) often seems more appropriate than Eigentum (property), although many German scholars prefer the composite expression Besitz und Eigentum ('possession and property') as a general designation of the field (Hann 2007: 290). Perhaps the term 'property' should be abandoned in cross-cultural analysis even if the language of 'rights' is retained, as Peters suggests (1998: 370).

As one of the few anthropologists to criticise anthropological approaches to property, Marilyn Strathern (1984) questions the applicability of this notion, and its underlying ontology, to Hagen in the Highlands of Papua New Guinea. 
Strathern asks, 'What do we mean by property?' The notion of rights, she argues, is embedded in the Western notion of property, which entails a radical disjunction between people and things. Property relations are represented not as a type of social relationship but as a relationship between people and things (Strathern 1984: 162). This is actually incorrect as far as legal discourse goes, for many legal textbooks explain the way in which property is defined as a relation between persons with respect to things. Strathern suggests that the disjunction between persons and things can be merged with that between 'subject' and 'object' in Marxist thought. There is a Western folk antithesis between treating someone as a person and as an object. As subjects, people manipulate things, and can cast other people into the role of things 'insofar as they can hold rights in relation to these others'; the 'acting subject' is recognisable by his or her 'rights' (Strathern 1984: 162).

Strathern argues that in Hagen, social relations are not necessarily bound up with a subject-object dichotomy or with attendant issues of control. Wealth or assets such as a clan estate or valuables represent an aspect of intrinsic identity so cannot be disposed of or withdrawn from the exchange system without compromising that identity. People exercise 'proprietorship' insofar as they have personal 'rights of disposal' over valuables and possessions - often regarded as the products of the person's labour, creativity or energy. These valuables and possessions are not alienable in the same way as commodities, for labour remains part of the person. Disposal is construed as a loss to the producer for which the producer is compensated, rather than the labour being purchased. When Hagen women are equated with wealth and become gifts in exchanges between men, they too are seen as an aspect of intrinsic clan identity and stand for aspects of the 'clan person'; women see aspects of themselves as bound to their identification with clan brothers. Thus, when men exchange women between clans, 'we may argue that it is part of themselves that men are exchanging' (Strathern 1984: 167), and in giving valuables the donor 'is giving himself' (p. 168). While suggesting that the language of 'rights' is bound up with inappropriate concepts of 'property', Strathern nonetheless mixes the language of property and rights (such as 'proprietorship' and 'rights of disposal') with the language of inalienable possession and intrinsic connection.

Paradoxically, Munn (1970) uses the terminology of 'subject' and 'object' to construe just that kind of cosmology, which posits intrinsic connections between persons and things. According to Munn, Warlpiri and Pitjantjatjara people are embedded in a moral universe constituted in part by objectifications of ancestors in the form of their traces and remains in the landscape and in the form of ancestral designs painted on bodies (for related Warlpiri material, see Curran and Morton, this volume). In Warlpiri and Pitjantjatjara thought, the ancestors first created the 'object world' out of themselves. An underlying 
pattern of ancestral transformation has a 'bi-directional structure' (Munn 1970: 156), which entails both objectification (especially of features of the landscape) through the agency of ancestors and identification by the living subject with those objects. Munn takes such transformations and relations of identification to be the grounds of the moral order. These contrasting uses of the subject/ object dichotomy come from Kantian philosophy, in which a subject is a person capable of knowledge and an object is something that is capable of being known (Kant 1933). The object as appearance has to be distinguished from the object as it is in itself, beyond the possibility of knowledge. Objects are objects for subjects and are conditioned by subjects. But the self can also be the object of knowledge. A subject is also a moral entity who is responsible for actions carried out, as distinct from an object that is acted upon.

Strathern (1984) takes 'property' in its sense in Western law, in which primary elements are taken to be the right to exclude others and the right to alienate, and to imply a radical distinction between persons and objects that are owned. Presumably, in the Highlands of New Guinea, as in Aboriginal Australia, beliefs and doctrines posit essential connections between persons and country (land and waters). It is in this sense that the 'subject/object' dichotomy can be said to be present in one ontological system and not in another. I think the contrast is overdrawn, however. Only recently in European history, people were owned and traded as slaves, and some regarded slaves as not being persons in a complete sense. The New York Times of 9 April 1860 argued, however, that the US Constitution did not classify slaves merely as property:

On the contrary, with studied and deliberate purpose, in each and every allusion which it makes to slaves, the Constitution speaks of them as persons - which they cannot possible be if they are solely and exclusively property. If they are persons, they have personal rights: they are subjects of moral law:- they have certain spiritual powers and faculties of which no laws can divest them, and which no human power can ignore or disregard without committing a moral wrong. Property has no such rights, - no such faculties. (The New York Times, 9 April 1860, p. 4, emphases in original)

The relation between a person and part of the person's body is also taken to be inimicable to a property relation, although this remains a grey area legally (Vines 2007).

A disadvantage of proposing radical differences in ontological categories, and in beliefs and doctrines about things that are possessed or owned, is that it precludes theories about how such relations come about, and variation in those relations. When land is a scarce and valued 'resource', as it is almost everywhere, then various means have come into play for the control of access to the resource. 
The kind of arrangement found in Australia - where country is imbued with totemic significance and tied to patrifilial or other kinds of groups, as in Peterson's (1972) analysis - has been called 'social boundary defence' (Cashdan 1983). In this approach, doctrines about the essential connections between persons and places are viewed (in part) as a means of allocating scarce and valued resources. Writers such as Von Benda-Beckmann et al. take 'property' to be a handy cover term for such arrangements. In using it in this way, its everyday meaning is qualified in a manner that is common in anthropological translation.

The problem with the dominance of the language of 'rights' and 'property' language, however, is that it obscures Indigenous concepts and discourse, as Hann (2007: 289) implies. Unfortunately, the majority of ethnographies simply translate ways of possessing things in terms of 'property' and of 'rights'. I have found very few that give any detailed indication of how such relations are expressed (and hence constituted) in Indigenous discourse. Strathern, for example, addresses Hagen concepts of persons and things, although we do not get a clear idea of how Hageners express these conceptions. If individuals are said to have 'rights' in the country of their mother's patri-clan as well as the father's, for example, how are these constituted in discourse and action, and does the term 'right' adequately capture the particulars of Indigenous deontology?

\section{Variation in the Language of Aboriginal Relations to Country}

What alternative analytical frameworks are available? In addition to Peterson's perspective on Yolngu relations to country, we find (at least) two contrasting approaches to 'owning' land and waters on the part of Yolngu people. The first translates Aboriginal conceptions and actions into the language of 'property' and 'rights'. The second, consistent with Strathern's critique, depicts Aboriginal connections to 'country' as involving an ontology that is somewhat distinct from a 'Western' one. As an example of the first, I turn to Williams' (1986) account of Yolngu land tenure.

Williams (1986) is not shy in using the term 'property' and what she calls the Yolngu 'concept of property' in explicating Yolngu 'principles and rules' governing the 'tenure' of land and waters on the part of landowning groups. Indeed, she quite deliberately uses concepts and definitions derived from common law to suggest equivalences between Yolngu ideas of landownership and those embodied in the common law (Williams 1986: 101). Thus, she writes of the 'jural order in the distribution of proprietary interests to land through time' (p. 104), and deploys terminology drawn from British and Australian law to explicate what she calls Yolngu 'tenure'. Williams had a good reason for 
taking this approach - namely, to prepare the way for future legal recognition of Yolngu relations to land in light of the findings of Blackburn J. in the Gove case, in which he rejected Yolngu claims to proprietary rights over their lands.

Like other Australianist anthropologists, Williams calls the land-holdings of a patrilineal landowning group its 'estate' (Stanner 1965), borrowing the legal term, which in the Yolngu case is not simply a parcel of land but consists of a cluster of two or more discrete areas (Williams 1986: 78). A landowning group is 'corporate' in virtue of holding such an estate (Williams 1986: 94). Tenure on the part of an owning group has a religious rationale in the journeys of spirit beings (p. 79). Myths vest land in named groups 'establishing ownership under right of title', and 'subsidiary categories of ownership are implied in a myth' (p. 102).

Ownership by a patrifilial landowning group is complemented by 'tenure in land based on relationship to [a] female land-owner' - primarily a person's mother and mother's mother. The relation is described as one of 'looking after' the estate (Williams 1986: 80). With the consent of the landowning group and its several uterine grandchildren (gutharra, wDC/ZDC), the relation to the mother's country may be inherited by male heirs of the waku (wC/ZC) in question (p. 80). Indeed, approval of the gutharra must be gained for 'the vesting of any kind of subsidiary right in an estate to which they are so related' (p. 80).

Small areas within a group's larger area may be held by a member or members of another landowning group as an 'interest' that is created with the consent of group members and their uterine descendants (primarily waku, $\mathrm{wC} / \mathrm{ZC}$, and gutharra, wDC/ZDC). The creation of an interest involves the 'vesting group' giving a sacred object representing some aspect of their land to the individual or group 'in whom they vest the subsidiary right', in order to 'validate that interest' (Williams 1986: 78). An individual may also be given a waterhole to 'look after' because his conception spirit was deemed to come from that place (p. 79), and a group may hold a small portion within an affinial group's estate (p. 80). These are all varieties of 'subsidiary rights'. Williams goes on to discuss the concept of 'permission' to visit the land of another group (pp. 84-5).

Williams (1986: 104) concludes that the Yolngu system of land tenure is characterised by groups which, in terms that common law can comprehend, are corporate with respect to their interests in land, and that those interests are proprietary'. It is from this perspective that Williams investigates the failure of Mr Justice Blackburn to find that Yolngu had proprietary interests in land in the Gove case, and translates Yolngu tenure of land and waters in such a way as to provide resources for rethinking that finding. 
It is clear from Williams' account that land and waters are far from being conceived of as inanimate 'objects' in Yolngu discourse, for the country and its spirits are addressed when a visitor is introduced. This does not inhibit Williams from using the language of property and rights, but she does provide a window into Yolngu concepts, although seldom reporting the corresponding expressions in Yolngu dialects. These dialects do not contain verbs 'to have' or 'to own', but they do include a large number of forms 'that allow Yolngu to express complex sets of rights and duties in all categories of property, and to express them as precisely as they wish' (Williams 1986: 102). Suffixes that denote possession create such forms, she writes. Presumably, Williams is referring here to the possessive suffix $g u / k u / w u$, as in ngarraku wa:nga: 'my country/place/ camp'. The form watangu is added to wa:nga ('place', 'camp', 'land') to denote 'owner of', and the relation of uterine relatives to an 'estate' is expressed using the same form. Thus, a woman's child is ngandi-watangu ('mother-owner') of his or her mother's country, and woman's daughter's child is ma:ri-watangu in relation to his or her mother's mother's country. Responsibility for land and waters is expressed in terms of 'looking after' (dja:ga) -for example, a person 'looks after' the country of his sister's child (waku) (Williams 1986: 93). The most senior man of a landowning group has responsibility for the most sacred site on the estate as a whole, while each parcel is the 'primary responsibility' of a mature man to 'look after' (p. 78). Members of the landowning group 'hold in their hands' the associated ritual 'property'. (The verb rendered in this way is presumably ngayathama, 'hold', or perhaps ga:ma, 'carry').

As a contrasting example of discourse about Yolngu relations to country, which lies (in part) outside the language of land and waters as objects of property rights, I turn to Magowan's (2001) construal of Yolngu conceptions of the ancestral significance of sea and fresh water. Magowan undertakes to re-evaluate the human-ancestor-land complex, especially in light of Munn's (1970) account of transformations of 'subjects' into 'objects' in Warlpiri and Pitjantjatjara thought discussed earlier.

Magowan emphasises the dynamic 'kinetic' properties of landscape (cf. Redmond 2001), and builds this into her account of Yolngu cosmology and relations to country and ancestors. Ancestral power, she writes, 'inheres in both topography and oceanography [sic] through its own natural movements and the actions of others upon it' (Magowan 2001: 23). Each ancestral transformation 'has its own dynamic and interactive agency arising from particular movement forms in the landscape and seascape', which are in perpetual motion (p. 23). In song, 'different configurations of co-substantive essences, allow apparently static topographical features to acquire human qualities because they image ancestral movement patterns' - a process that she refers to as 'polymorphism' (p. 23), a term used in Christian theology. 
Whereas Stanner (1966: 260-2) interpreted a man as saying that a person and their totem were 'like' one another - 'simulation' in Magowan's terminologyaccording to her interpretation, Yolngu posit 'a closer ontological relationship between subjects and objects as one of simultaneity': a person will say 'I am the water' or 'I am the tree'. (There is, however, no equivalent to the verb 'to be' in Yolngu languages.) Embedded in such statements are ideas about how Yolngu 'view themselves as multiple, simultaneous entities encompassing and encompassed by the landscape and seascape' (Magowan 2001: 24). Thus, in Yolngu ideas of sea cosmology, 'humans, ancestors and waters are interlinked by a combination of the various shapes, forms, colours and sounds of water movements in, through and upon the land' (p. 25). People are perceived as ancestors in ritual performance and song, which evoke "movements of the ancestral past in the landscape and seascape' (p. 25).

Drawing on Bagshaw's (1998) use of the term 'consubstantiation' to capture the relation between a patri-group and its country, Magowan discusses the gendered identity of bodies of sea water and fresh water, each identified with a particular patrimoiety. Relations between waters provide images in song of conjugal union, insemination and conception. For example, a reference to Dhuwa moiety salt water 'provides an image of male waters covering the female freshwater as it runs into the sea, inseminating the singer's mother'. Indeed, Yirritja moiety names are found in Dhuwa waters and vice versa; as one man explained to Magowan (2001: 27), 'it's not all neatly cut up into boundaries'.

Thus, waters are 'ancestral subjects' with their own recognised agency and kinesis (for example, in the motion of waves). Songs about water 'embody human agency in movements that express the consummation of marriage between people through the mingling and swirling of waves, depicting the conjoining of two individuals' (Magowan 2001: 27). The intermingling of fresh and salt water is termed ganma, with connotations of sexual relations and the mixing of bodily fluids (see also Keen 1991b). Patterns of movement connecting humans, ancestors and the sea enable body parts and ancestors to be seen as conterminous with one another, although the relationship between their parts is multivalent and multifarious. In song, strings of entities connected by aspects of shape and form can be 'imaged as simultaneously subsumed inside the other' as a song series progresses. Thunderman is identified as cloud and the carrier of water in song and as emptying his contents of rain as he hunts with his spear (Magowan 2001: 28). As noted earlier, Magowan (2001: 27) labels these relations and processes 'polymorphism', which is 'the process whereby an ancestor, human or part of the landscape or seascape is seen as being simultaneously held inside the other'.

Magowan thus coins terms to capture subtleties of Yolngu cosmological discourse (especially in song). She also deploys the language of 'rights', however: 'The ways that songs are performed and the claims that singers make to ancestral 
subjects have political implications for the assertion of group rights to land ownership and marine tenure across the whole north east Arnhem land region' (Magowan 2001: 23). Drawing on the language of the Aboriginal Land Rights (Northern Territory) Act (1976), the 'managers' of a particular 'homeland' and its associated watercourses have a 'primary responsibility' for their area:

However, as ancestral features of the landscape-seascape complex are shared with groups who relate as mothers to the managers of the opposite moiety, these groups also share rights in their waters. In song performance, it is possible to indicate which groups have these additional rights since the managing group will sing of the ancestral being or objects of the opposite moiety. (Magowan 2001: 26)

How do Magowan's representations of complex ideas about the identification of persons, ancestors and places, with emphasis on the movement and intermingling of bodies of water identified with groups and persons as well as totemic ancestors, articulate with talk of the 'rights' of persons and groups? The language of 'rights' belongs to the property paradigm, whereas Magowan's construal of polymorphism and consubstantiation in Yolngu cosmology belongs to a different universe of discourse.

\section{Resources and Social Boundary Defence}

These analytical languages come together to some extent in theories about the evolution and functions of ancestral cosmologies in relation to land and waters. Theorists of risk (for example, Smith 1988) link the forces that determine movement to the control of access to land, waters and their resources. With dense resources and predictable returns, the cost of boundary defence is less than the benefit, so that people will tend to guard the boundaries of exclusive territories - a system that prevailed on the north-western coast of North America. With sparser, more unpredictable resources, it pays people to permit reciprocal but controlled access to resources. 'Social boundary defence' (Cashdan 1983) achieves this end. People differentiate between those with unequivocal rights in a given area and those who ought to obtain permission to visit and use its resources. In many (perhaps all) regions of Australia, some form of social boundary defence was in place, but the degree of exclusivity varied between regions and with the kind of resource (Keen 2004; see also Dyson-Hudson and Smith 1978; Heinz 1972; Kelly 1995: 184-95, 203; Smith 1988).

Totemic ancestral cosmologies can be seen in part as underwriting modes of social boundary defence. In northeast Arnhem Land, for example, those who are most closely identified with a country (land and waters) and its ancestral places through 'consubstantiation' have the strongest rights and attachments - these 
are Williams' 'owners'. They do not enjoy exclusive use of country, however. Others with close kinship links to the wa:nga-watangu (country-holders) also have access and also have responsibilities to their mother's and mother's mother's country and its ancestral law (madayin). This structure can be seen as a way of controlling access and use in an orderly way, according to regionally shared ancestral law (rom), without enjoining exclusive rights. Yet the division between kinds of language of property remains.

\section{Reconciling Terminologies}

How can these analytical languages be reconciled, or are they incommensurable? The myths linking a group to its sites and country in Williams' account, and the connections of consubstantiality analysed by Magowan, as well as kinship links to 'owners', can be said to provide grounds or reasons for ownership and subsidiary 'rights'. This is one way of reconciling them; yet for Strathern the language of property and rights is incompatible with consubstantial connections, for land and waters in such a cosmology are not 'objects' to be possessed as 'property'.

Another way to bring these positions closer-one that would overcome the Strathernian objection - would be to investigate the ways in which relations described as 'rights' are constituted in Indigenous discourse. Williams mentions the use of the possessive case to express possession, as in ngarraku wa:nga, 'my country', and ngarraku ngandi wa:nga, 'my mother country'. We have seen that a person is wa:nga-watangu ('country-owner') of their country through the father, and ngandi-watangu ('mother-owner') of their mother's country, and so on. Responsibility for various categories of country is expressed as 'looking after' (dja:ga) the places. But as far as I know, anthropologists have not described how 'rights' are expressed or asserted in Yolngu languages-for example, in disputes. To describe Indigenous expressions of social powers and constraints of a kind that become translated as rights and obligations could draw them closer to expressions of totemic connections, especially where religious discourse and the discourse of 'rights' come together, as when framing reasons for such powers and constraints.

Where does Peterson's approach fit in to this picture? Especially in the context of hunting and gathering societies, the control of resources requires appropriate distribution of people in space-a process that Peterson has described in terms of territoriality and spacing mechanisms, a key element of which is the affective attachment of senior males to their land and waters. Peterson's theory seems to be compatible with accounts both in terms of rights and property and consubstantiation, for attachment to country could in principle be rationalised 
or supported by assertions expressed in (or translated into) either kind of terminology. Such a process is a matter of the control of access to resources and points to presumably universal motivations underlying discourses of social powers and (in the Yolngu case) ancestral connections. This kind of terminology and mode of analysis cannot be challenged by appeal to the particularities of cultural constructions, I think, for these are seen as culturally specific means (for example, totemic connections) to universal ends (for example, adaptive disposition of a population in space). To challenge them requires appeal to other grounds.

\section{Acknowledgments}

The research on which this chapter is based was funded in part by the Australian Research Council and the National Museum of Australia through a Linkage grant. Thanks are due to Heather Leasor for assistance with the research on which this chapter is based, and to Marcus Barber and Yasmine Musharbash for editorial guidance. I am grateful to Bree Blakeman for comments on an earlier draft of the chapter, and to participants in the joint anthropology seminar at The Australian National University at which this chapter was presented for their comments, especially Patrick Guinness, Francesca Merlan, Kevin Murphy, Alan Rumsey and James Weiner.

\section{References}

Alchian, A. A. and H. Demsetz, 1973. The property rights paradigm. The Journal of Economic History 33 (1): 16-27.

Bagshaw, G. 1998. Gapu dhulway, gapu maramba: conceptualisation and ownership of saltwater among the Burarra and Yan-nhangu peoples of northeast Arnhem Land. In N. Peterson and B. Rigsby (eds), Customary Marine Tenure in Australia, pp. 154-77. Sydney: University of Sydney.

Barnard, A. and J. Woodburn, 1991. Introduction. In T. Ingold, D. Riches and J. Woodburn (eds), Hunters and Gatherers. Volume 2: Property, Power and Ideology, pp. 4-31. Oxford: Berg.

Bartlett, R. H. 1993. The Mabo decision: commentary. In The Mabo Decision, pp. 236-61. Sydney: Butterworths.

Callies, R. P. 1971. Eigentum als Institution: Aspekte zür Theorie des Institutions. In A. Kaufmann (ed.) Rechtstheorie: Ansätze zu einem kritischen Rechstverständnis, pp. 142-74. Karlsruhe, Germany: C. F. Miller. 
Cashdan, E. 1983. Territoriality among human foragers: ecological models and an application to four Bushman groups. Current Anthropology 24: 47-66.

Davies, M. and N. Naffine, 2001. Are Persons Property? Legal Debates about Property and Persons. Aldershot, UK: Ashgate.

Dyson-Hudson, R. and E. A. Smith 1978. Human territoriality: an ecological reassessment. American Anthropologist 80 (1): 21-41.

Fortes, M. 1958. Introduction. In J. R. Goody (ed.) The Developmental Cycle in Domestic Groups, pp. 1-14. Cambridge: Cambridge University Press.

Goody, J. 1962. Death, Property and the Ancestors. Stanford: Stanford University Press.

Gordon, R. 1995. Paradoxical property. In J. Brewer and S. Staves (eds), Early Modern Conceptions of Property, pp. 95-110. London and New York: Routledge.

Grey, K. 1991. Property in thin air. Cambridge Law Journal 50 (2): 252-307.

Hann, C. M. 1998. Introduction: the embeddedness of property. In C. M. Hann (ed.) Property Relations: Renewing the Anthropological Tradition, pp. 1-47. Cambridge: Cambridge University Press.

Hann, C. M. 2007. The state of the art: a new double movement? Anthropological perspectives on property in the age of neoliberalism. Socio-Economic Review 5: 287-318.

Harris, J. W. 1996. Property and Justice. Oxford: Oxford University Press.

Heinz, H. 1972. Territoriality among the Bushmen in general and the !Ko in particular. Anthropos 67: 405-16.

Hiatt, L. R. 1962. Local organisation among the Australian Aborigines. Oceania 32: $267-86$.

Hohfeld, W. N. 1913. Some fundamental legal conceptions as applied in judicial reasoning. Yale Law Journal 23: 16-59.

Hohfeld, W. N. 1917. Fundamental legal conceptions as applied in judicial reasoning. Yale Law Journal 26: 710-70.

Kant, I. 1933. Critique of Pure Reason. N. Kemp Smith (trans.). London: Macmillan and Co.

Keen, I. 1991a. Yolngu religious property. In T. Ingold, D. Riches and J. Woodburn (eds), Property, Power and Ideology in Hunting and Gathering Societies, pp. 272-91. London: Berg. 
Keen, I. 1991b. Images of reproduction in the Yolngu Madayin ceremony. In W. Shapiro (ed.) Essays on the Generation and Maintenance of the Person in Honour of John Barnes. Mankind Special Issue, pp. 192-207.

Keen, I. 2004. Aboriginal Economy and Society: Australia at the Threshold of Colonisation. Melbourne: Oxford University Press.

Kelly, R. L. 1995. The Foraging Spectrum: Diversity in Hunter-Gatherer Lifeways. Washington, DC, and London: Smithsonian Institution Press.

Lowie, R. 1947. Primitive Society. New York: Liveright Publishing Corporation.

Magowan, F. 2001. Waves of knowing: polymorphism and co-substantive essences in Yolngu sea cosmology. The Australian Journal of Indigenous Education 29 (1): 22-35.

Morphy, F. 2008. Whose governance, for whose good? The Laynhapuy Homelands Association and the neo-assimilationist turn in Indigenous policy. In J. Hunt, D. Smith, S. Garling and W. Sanders (eds), Contested Governance: Culture, Power and Institutions in Indigenous Australia. CAEPR Monograph No. 29, pp. 113-252. Canberra: ANU E Press.

Munn, N. 1970. The transformation of subjects into objects in Walbiri and Pitjantjatjara myth. In R. M. Berndt (ed.) Australian Aboriginal Anthropology, pp. 141-63. Nedlands: University of Western Australia Press.

Olivecrona, K. 1971. Law as Fact. London: Stevens and Sons.

Penner, J. E. 1995-96. The 'bundle of rights' picture of property. UCLA Law Review 43: 711-820.

Penner, J. E. 1997. The Idea of Property in Law. Oxford: Oxford University Press.

Peters, P. E. 1998. The erosion of commons and the emergence of property: problems for social analysis. In R. C. Hunt and A. Gilman (eds), Property in Economic Context. Lanham, Md: University Press of America.

Peterson, N. 1971. The Structure of Two Australian Aboriginal Ecosystems. PhD Thesis, University of Sydney, NSW.

Peterson, N. 1972. Totemism yesterday: sentiment and local organisation among the Australian Aborigines. Man 7 (1): 12-32.

Peterson, N. 1985. Capitalism, culture and land rights: Aborigines and the state in the Northern Territory. Social Analysis 18: 85-101.

Peterson, N. 2006. 'I can't follow you on this horde-clan business at all': Donald Thomson, Radcliffe-Brown and a final note on the horde. Oceania 76 (1): 16-26. 
Pottage, A. 1998. Instituting property. Oxford Journal of Legal Studies 18: 331-44.

Redmond, A. 2001. Places that move. In A. Rumsey and J. F. Weiner (eds), Emplaced Myth: Space, Narrative, and Knowledge in Aboriginal Australasia and Papua New Guinea, pp. 120-38. Honolulu: University of Hawai'i Press.

Rey, H. 1977. Dynamisiertes Eigentum. Zeitschrift für Schweizerisches Recht 65.

Shapiro, W. 1973. Residential grouping in northeast Arnhem Land. Man [n.s.] 8 (3): 365-83.

Smith, E. A. 1988. Risk and uncertainty in the 'original affluent society': evolutionary ecology of resource sharing and land tenure. In T. Ingold, D. Riches and J. Woodburn (eds), Hunters and Gatherers. Volume I: History, Evolution, and Social Change, pp. 222-51. Oxford: Berg.

Stanner, W. E. H. 1965. Aboriginal territorial organisation: estate, range, domain and regime. Oceania 36 (1): 1-26.

Stanner, W. E. H. 1966. On Aboriginal Religion. Oceania Monographs 11. Sydney: University of Sydney.

Strathern, M. 1984. Subject or object? Women and the circulation of valuables in Highlands New Guinea. In R. Hirschon (ed.) Women and Property: Women as Property, pp. 158-75. London and Canberra: Croom Helm; New York: St Martin's Press.

Van der Walt, A. J. 1992. The fragmentation of land rights. South African Journal on Human Rights 8: 431-50.

Vines, Prue 2007. The sacred and the profane: the role of property concepts in disputes about post-mortem examination. University of New South Wales Faculty of Law Research Series 13: 1022.

Von Benda-Beckmann, F., K. von Benda-Beckmann and M. G. Wiber, 2006. The properties of property. In T. van Meijl and F. von Benda-Beckmann (eds), Property Rights and Economic Development: Land and Natural Resources in Southeast Asia and Oceania, pp. 1-39. London: Kegan Paul International.

Williams, N. 1986. The Yolngu and their Land: A System of Land Tenure and the Fight for its Recognition. Canberra: Australian Institute of Aboriginal Studies.

Worthington, S. 2006-07. The disappearing divide between property and obligation: the impact of aligning legal analysis and commercial expectation. Texas International Law Journal 42: 917-39. 